\title{
Implementation of Subsidized Fuel Policy in Gorontalo City
}

\author{
Sakbir $^{1}$, Rusly Abdurahman Idji ${ }^{1}$ \\ ${ }^{1}$ Public Administration Study Program, Muhammadiyah University of Gorontalo, Indonesia \\ Received: November 5, 2020 \\ Received in Revised: November 27, \\ Accepted: December 11, 2020 \\ 2020
}

\begin{abstract}
This study aims to determine the implementation of the subsidized fuel oil (BBM) policy in Gorontalo City. The method used in this research is descriptive qualitative. Data collection techniques used interview techniques and focus group discussion (FGD). The results showed that the communication of the implementation of the subsidized fuel policy in the city of Gorontalo was well implemented. The socialization was carried out through coordination with all relevant stakeholders, the unfolding of notification banners related to the Subsidized Fuel policy at each gas station point. Resources in order to support the implementation of the subsidized fuel policy in Gorontalo City are not sufficient. It can be seen from the minimal number of gas stations that distribute subsidized fuel and the low volume of fuel supplied for each subsidized fuel. The attitude of the implementer / disposition towards the subsidized fuel policy in Gorontalo City is not very good. It can be seen from the attitude of the government and other stakeholders that they do not care about the distribution of subsidized fuel to nontarget groups, as in this case it is given to retailers only. The bureaucratic structure does not work optimally, it can be seen from the absence of officers from either the government, Pertamina or other stakeholders at each gas station point who should be in charge of controlling and supervising the distribution of Subsidized Fuel.
\end{abstract}

Keywords: Implementation, Subsidized Fuel (BBM), Policy

\section{Introduction}

Government policies related to the One Price Fuel (BBM) program are stipulated through the Minister of Energy and Mineral Resources by issuing the Minister of Energy and Mineral Resources because so far there has been a large price gap between the selling price of fuel on the island of Java and areas outside Java, especially in the eastern part of Indonesia. In principle, the basis for the Government is to realize that Indonesia as a unitary state does not discriminate between fuel prices in Indonesia. Once again, the Government through this policy wants to promote justice and equity in Indonesia in accordance with the fifth principle "Justice for all Indonesian people" so that there are no more gaps between regions. However, this policy certainly carries a very big risk because the one price fuel policy will be pursued through the provision of subsidies which will later burden the state budget or related parties.

In the eastern part of Indonesia, especially for small areas such as Gorontalo City, the supply of subsidized BBM, in this case Assignment BBM or subsidized BBM such as diesel and premium, is very difficult for target groups to obtain from government policy itself. The biggest problem is when the community as the target group of the birth of the government policy on subsidized fuel and one price is not really enjoyed by the community but only enjoyed by a group of people who have the status of a retailer. The facts in the field to date show that every gas station point in Gorontalo City always displays a long queue to get subsidized fuel and unfortunately there are no people in the long queue as the target group of the policy but are controlled by retailers with vehicles where the tank is positioned. The 
motor has been modified to accommodate more fuel. It is not surprising that in a matter of hours the subsidized BBM has been sold out and the community as the target group has only two options, namely buying subsidized fuel at retailers at a price of 9 thousand to 10 thousand per liter or buying non-subsidized fuel.

Keban (2004) states that public policy can be seen as a philosophical concept, as a product, as a process, and as a framework". Furthermore, it can be explained as; Policy as a philosophical concept is a set of principles or desired conditions; as a product, policy is seen as a series of conclusions or recommendations; as a process, policy is seen as a way through which an organization can find out what is expected of it, namely programs and mechanisms in achieving its products; and as a framework, policy is a process of bargaining and negotiation to formulate issues and methods of implementation. According to Dunn (2000), the public policy analysis process is a series of intellectual activities carried out in a process of activities that are basically political in nature. This political activity is described as a policy-making process, and is visualized as a series of interdependent stages arranged in a chronological order, which includes agenda setting, policy formulation, policy adoption, policy implementation, and policy assessment. Meanwhile, intellectual activities include problem formulation, forecasting, policy recommendations, monitoring and policy evaluation.

\section{Policy Implementation}

Implementation is one of the stages in the public policy process. Usually implementation is carried out after a policy has been formulated with clear objectives. Implementation is a series of activities in order to deliver policies to the public so that these policies can bring the expected results (Gaffar, 2009). In simple terms implementation can mean implementation or application. Nurdin and Usman (2009) suggest implementation as an evaluation. "Implementation is the expansion of activities that adjust to each other". Understanding implementation as activities that adjust to each other".

The definitions above show that the word implementation boils down to activity, the existence of an action, action, or mechanism of a system. The expression mechanism implies that implementation is not just an activity, but an activity that is planned and carried out in earnest based on the reference to certain norms to achieve the objectives of the activity. Policy implementation is a crucial stage in the public policy process. Implementation is one of the stages since the various stages of public policy. This means that policy implementation is only one of the variables that influence the success of a policy in solving public problems. According to Edwards III. (in Subarsono 2011: 90) where implementation can be started from an abstract condition and a question can be successful. Edwards III stated that "there are four variables in public policy, namely communications, resources, attitudes (depositions or attitudes) and the bureaucratic structure (bureaucratic structure)".

The factors that influence implementation according to Edward III (in Subarsono 2011) are communication, resources, deposition or attitude, bureaucratic structure. These four factors must be implemented simultaneously because each other has a close relationship, our goal is to increase understanding of policy implementation.

\section{Approach to Public Policy Implementation}

The implementation of public policy has a scientific approach. Therefore, the policy implementation approach needs to pay attention to the characteristics shown in the scientific approach as stated by Abidin (2004) that in the scientific approach there are several things that need to be considered: such as; data collection and analysis is objective or unbiased. In a scientific approach, analysis is carried out after obtaining data objectively. Thus, it is hoped that information can be obtained about certainty in the implementation of a policy that is 
ready to be implemented; Directed data collection. For the sake of policy implementation, accurate and targeted data is needed so that each policy product can be implemented in accordance with the substance of the policy product; Use of relevant measures or criteria; Clear policy formulation.

\section{Subsidized Fuel Oil}

Subsidies are assistance provided by the government to consumers or producers so that the goods and services produced are priced lower and the amount purchased by the community is greater. Subsidies (Goverment transfer payment) are government policy tools for redistribution and stabilization. According to the Oxford Advanced Learners Dictionary (1990) in Chinyere \& Ani Casimir's (2013) research, subsidies are

"The money that is paid by a government or organization to reduce the cost of services or of producing goods so that their prices can be kept low".

As for several main bases in the application of subsidies, among others; A useful assistance provided by the government to groups or individuals in the form of cash payments or tax breaks; Given with the intention of reducing the burden borne by groups or individuals and can also focus on benefits or benefits for the community; Subsidies are also obtained from taxation, which is one of the revenues collected by the government and will be returned to the community in the form of subsidies. With the subsidy, the government hopes that the price of goods will be lower. The government here bears part of the production and marketing costs. In essence, subsidies are provided to help lower middle class groups or those with weak purchasing power, not those with high purchasing power (Susilo 2013).

According to Bappenas (2007), subsidies basically have a function as; means of equalizing output through a mechanism of increasing the elasticity of demand; price stability tools through price intervention mechanisms; and output optimization tools through the supply elasticity mechanism. Fuel oil (BBM) is a type of fuel that is produced from refining crude oil. The crude oil from the bowels of the earth is processed in the refining process to produce oil products which include fuel oil. The factors that affect fuel subsidies are the price of crude oil on the world market, the ability of oil refineries to process crude oil into fuel, imports of fuel products, the rupiah exchange rate against US Dollar, the volume of domestic fuel consumption.

Fuel subsidies have an impact on the selling price of fuel oil in the country to be cheaper than the initial price before being subsidized, thus making it easier for people to obtain BBM and this makes public consumption of fuel subsidies increase. The negative impacts that can arise from fuel subsidies are unfair, burdensome APBN, wasteful use, accelerating Indonesia to become a net importer, alternative energy is difficult to develop because it cannot compete with subsidized fuel (Susilo, 2013).

\section{Methods}

The type of research used by researchers is descriptive research with a qualitative approach. This research was conducted at several gas stations in Gorontalo City. Sources of data for the purpose of research include: (a) primary data sources and (b) secondary data sources. Activities or data collection activities carried out in this study include several techniques, namely: (a) observation techniques, (b) interview techniques, and (c) documentation techniques. To analyze how the implementation of the subsidized fuel policy in Gorontalo City, qualitative analysis techniques are used which include: (a) data reduction, (b) display data, and (c) conclusion / verification.

\section{Results and Discussion}




\section{Implementation of Subsidized Fuel Policy in Gorontalo City}

Subarsono (2011) argues that policy implementation is influenced by four variables, namely; communication, resources, executive attitudes / dispositions, and bureaucratic structures. The following is a description of the discussion related to the implementation of the subsidized fuel policy in Gorontalo City.

\section{Communication}

Communication will greatly determine the success of achieving the goals of public policy implementation. Effective implementation occurs when decision makers already know what they are going to do. Knowledge of what they are doing can work if communication goes well, so that any policy decisions and implementation regulations can be transmitted (or communicated) to the appropriate personnel department. In addition, the communicated policies must be precise, accurate and consistent. Edwards III stated that there are several dimensions in the communication aspect, including the dimensions of transmission (transmission), clarity (clarity), and consistency (consistency).

According to Edward III in Hanifah, (2012), communication is defined as "the process of delivering communicator information to communicants". Information about public policy according to Edward III in Subarsono, (2011) needs to be conveyed to policy actors so that policy actors can know what they have to prepare and do to carry out the policy so that policy goals and objectives can be achieved as expected.

One form of communication in policy implementation is socialization. A policy must first be introduced to the target group so that it can facilitate the implementation of activities and the achievement of goals can be obtained precisely. The communication meant in this research is an effort to socialize the subsidized fuel policy in Gorontalo City.

Based on the explanation of the informants interviewed by the researcher, it can be reaffirmed that the Gorontalo City Government together with other stakeholders such as pertamina Marketing Unit VII and Forkopinda, SPBU Owners have socialized the Subsidized Fuel policy. The socialization activities were carried out through Forkopinda coordination meetings, coordination with internal and external parties. In addition, the subsidized fuel policy is also carried out by displaying a notification banner related to the subsidized fuel policy and prohibiting the sale of subsidized fuel to parties specified in the law.

\section{Resources}

Subarsono, (2011) Resources are important in implementing good policies. Indicators used to see the extent to which resources affect policy implementation such as staff. The main resources in policy implementation are staff or staff (street-level bureaucrats). Failure that often occurs in policy implementation, one of which is caused by insufficient, insufficient, or incompetent staff / employees in their respective fields. Increasing the number of staff and implementers alone is not enough to solve the problem of policy implementation, but it requires a sufficient staff with the necessary skills and abilities (competent and capable) in implementing policies. A resource is a potential value possessed by a certain material or element in life. Resources are not always physical, but also non-physical (intangible). The encyclopedia defines resources as: (1) Ability to fulfill or handle something, (2) Sources of supplies, support or assistance, and (3) Means produced by one's abilities or thoughts.

In a general sense, a resource is defined as something that is seen as having economic value. It can also be said that resources are components of ecosystems that provide goods and services that are beneficial to human needs. Edward III in Subarsono, (2011) states that the resource factor has an important role in policy implementation. According to Edward III in 
Subarsono, (2011) that these resources include human resources, budget resources, and equipment resources and authority resources.

The resources meant in this study are the availability of supporting facilities and infrastructure in implementing the subsidized fuel policy. From the results of tracing information through several interviews with several informants, it was confirmed that the existing resources do not support the subsidized fuel policy in the City of Gorontalo. The 8 SPBU points in Gorontalo City, there are only 5 SPBUs that distribute subsidized premium and diesel fuel, which are the types of fuel with the most enthusiasts. Another result of the interview with several informants was the supply of subsidized fuel, which was deemed insufficient compared to demand. Based on the analysis of the interview results supported by relevant data and documents, it can be confirmed that the supporting resources for the subsidized fuel policy in Gorontalo City are yet inadequate.

\section{Executor's Attitude}

If the implementers have a positive tendency or attitude or support for policy implementation, there is a high probability that the policy implementation will be carried out in accordance with the initial decision. On the other hand, if the implementers have a negative attitude or refuse to implement policies because of conflicts of interest, the implementation of the policies will face serious obstacles. According to Van Metter and Van Horn in Agustino (2014), "the attitude of acceptance or rejection of policy implementing agencies greatly affects the success or failure of public policy implementation. This is very possible because the policies implemented are not the result of the formulation of local residents who are very familiar with the problems and problems they feel. However, public policies are usually of a nature which allows decision makers not to know or even to be able to address the needs, wants or problems that must be resolved".

The attitude of the implementer or disposition is the willingness, desire and tendency of policy actors to carry out a policy seriously so that what is the goal of the policy can be realized. (Lubis \& Daryanto, 2019; Cairney, 2019; Laurens et al, 2020). The attitude meant in this study is the behavior of the implementers in implementing the subsidized fuel policy. Based on the results of interviews obtained by researchers from several informants, it shows that the attitude of the implementers in the field is still lacking, especially in terms of action. Stakeholders ignore the misuse of subsidized fuel that occurs at each gas station. It has become a common sight in this city about the long queues at every gas station, especially at the subsidized fuel counter, even the queue occurs before the gas stations make a sale. The worse thing is that those who queue are dominated by retailers who bring vehicles with motorized tanks or cars that have been modified to get a larger amount of Subsidized Fuel.

Based on the researcher's analysis of the results of interviews with several informants supported by observations and documents, it is confirmed that the attitude of the implementers in implementing the Subsidized BBM policy in Gorontalo City is not so good that the subsidized BBM policy is not right on target.

\section{Bureaucratic Structure}

One of the variables that affects the success rate of implementing public policy is bureaucracy. Even if the resources to implement a policy are available, or policy implementers know what should be done, and have the desire to implement a policy, it is possible that the policy cannot be implemented or realized because of weaknesses in the bureaucratic structure (Morris \& Scott, 2003; Wang \& Ap, 2013; Syam et al, 2018). The bureaucratic structure referred to in this study is the existence of a bureaucratic structure that 
connects the performance of the central government to the local government level in implementing the subsidized fuel policy.

Based on the researcher's analysis of the results of interviews with several informants supported by observations and documents, it was confirmed that the bureaucratic structure was not working optimally, it was seen from the absence of officers from either the government, Pertamina or other stakeholders at each gas station point who should be in charge of controlling and Supervision of the distribution of Subsidized BBM.

\section{Conclusion}

The communication aspect in implementing the Subsidized BBM policy in Gorontalo City has been well implemented. The socialization was carried out through coordination with all relevant stakeholders, the unfolding of notification banners related to the Subsidized Fuel policy at each gas station point. Resources in order to support the implementation of the subsidized fuel policy in Gorontalo City are not sufficient. It can be seen from the minimal number of gas stations that distribute subsidized fuel and the low volume of fuel supplied for each subsidized fuel. The attitude of the implementer / disposition towards the subsidized fuel policy in Gorontalo City is not very good. It can be seen from the attitude of the government and other stakeholders that they do not care about the distribution of subsidized fuel to nontarget groups, as in this case it is given to retailers only. The bureaucratic structure does not work optimally, it can be seen from the absence of officers from either the government, Pertamina or other stakeholders at each gas station point who should be in charge of controlling and supervising the distribution of subsidized fuel.

\section{References}

Abiding, (2010). Kebijakan Publik dan Penerapannya. Jakarta. Bumi Aksara.

Afan Gaffar, (2008). Teori Implementasi Kebijakan Public. Sinar Grafika Offset, Jakarta

Agustino, Leo, (2014). Dasar-Dasar Kebijakan Publik. Alfabeta. Bandung

Cairney, P. (2019). Understanding public policy. Red Globe Press.

Guntur, (2009). Evaluasi Kebijakan Publik. Raja Grafindo Persada. Jakarta.

Hanifah, (2012). Kebijakan Publik Formulasi, Implementasi dan Evaluasi. Gramedia. Jakarta.

Laurens, S., Yusriadi, Y., \& Zulkifli, Z. (2020). Effectiveness of Organizational Design through Implementation of Regional Development Policy. In Proceeding of International Conference on Engineering, Technology, and Social Sciences (ICONETOS) (Vol. 1, No. 1, pp. 58-64).

Lubis, R., \& Daryanto, E. (2019). Policy Analysis of Internal Quality Assurance System (Case study at Midwifery Major of Poltekkes Kemenkes Medan. In 4th Annual International Seminar on Transformative Education and Educational Leadership (AISTEEL 2019). Atlantis Press.

Marzuki. (2012). Metodologi Riset. Yogyakarta: BPFE-UII.

Morris, P., \& Scott, I. (2003). Educational reform and policy implementation in Hong Kong. Journal of Education Policy, 18(1), 71-84.

Muhammadi (2011). Prinsip-Prinsip Perumusan Kebijakan Negara, Jakarta, PT.Bumi Aksara. Mustari, (2013). Teori Implementasi Kebijakan Public. Sinar Grafika Offset. Jakarta 
Nur Indriantoro dan Bambang Supomo. (2009). Metodologi Penelitian Bisnis. Yogyakarta:BPFE.

Subarsono, AG. (2011). Analisis kebijakan Publik : Konsep. Teori dan Aplikasi.Yogyakarta :Pustaka Pelajar.

Subyantoro, Arief., \& Suwarto, FX (2009) Metode \& Teknik Penelitian Sosial, Cetakan Kesepuluh, Yogyakarta : Penerbit Andi

Sugiyono, (2013). Metode Penelitian Pendidikan Pendekatan Kuantitatif, kualitatif, dan R\&D. Alfabeta. Bandung

Syam, H., Akib, H., Patonangi, A. A., \& Guntur, M. (2018). Principal entrepreneurship competence based on creativity and innovation in the context of learning organizations in Indonesia. Journal of Entrepreneurship Education, 21(3), 1-13.

Usman, Nurdin (2009). Konteks implementasi, Jakarta : PT Raja Grafindo Persada

Wang, D., \& Ap, J. (2013). Factors affecting tourism policy implementation: A conceptual framework and a case study in China. Tourism Management, 36, 221-233. 